Pamiętnik Literacki 2018, 4, s. 65-85

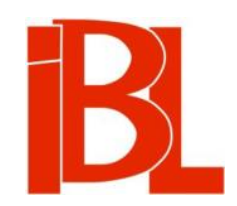

\title{
"Zuzanna" Jana Kochanowskiego wobec konwencji wernakularnych pieśni hagiograficznych
}

Dorota Vincůrková 
Pamiętnik Literacki CIX, 2018, z. 4, PL ISSN 0031-0514

DOI: $10.18318 / \mathrm{pl} .2018 .4 .4$

DOROTA VINCŮRKOVÁ Uniwersytet Szczeciński

\title{
„ZUZANNA” JANA KOCHANOWSKIEGO WOBEC KONWENCJI WERNAKULARNYCH PIEŚNI HAGIOGRAFICZNYCH*
}

\begin{abstract}
Psalmy syłam, gdzie kogo nabożnego słyszę, A Fraszki zaś dla dobrych towarzyszów piszę; Sobótka paniom służy; gracze odprawuję Szachami, a wesołe Pieśniami daruję ${ }^{1}$.
\end{abstract}

Jednym z wczesnych utworów Jana Kochanowskiego jest Zuzanna. Tekst ten ukazał się w drukarni Macieja Wirzbięty w 1561 lub 1562 roku i został zadedykowany Elżbiecie z Szydłowieckich Radziwiłłowej, żonie Mikołaja Czarnego ${ }^{2}$. Znajomość daty jej śmierci (20 VI 1562) ułatwiła badaczom ustalenie chronologii powstania owego poematu ${ }^{3}$. Osoba adresatki dzieła wpłynęła zasadniczo na jego formę - Kochanowski dopasował ją do upodobań arystokratki i do jej świadomości literackiej ${ }^{4}$ - co chcę w tym artykule udowodnić.

Zuzanna Kochanowskiego opowiada biblijną historię zawarta w rozdziale 13 Księgi Daniela ${ }^{5}$. Czarnoleski poeta taki właśnie utwór zadedykował Radziwiłłowej, kalwinistce ${ }^{6}$.

* Praca powstała pod opieką naukową dr. hab. Witolda Wojtowicza.

1 J. Ko ch a now ski, Na swe księi do Łaskiego. W: Dzieła polskie. Oprac. J. Kr zy ża n ow s ki. T. 2. Wyd. 5. Warszawa 1967, s. 59.

2 Zob. M. Kar plu k, J. P i r oży ń s ki, „O nieuwiarowaniu śmierci” - rękopiśmienna relacja świadka ostatnich dni Elżbiety z Szydłowieckich Radziwiłłowej (4-20 VI 1562). Miscellanea staropolskie. 6. Red. T. Ulewicz. Wrocław 1990, s. 65.

3 Zob. J. Zi o me k, Renesans. Warszawa 1980, s. 260. - R. Krzywy, Zuzanna- biblijna miniatura epicka $z$ teza. W: Sztuka wyborów i dar inwencji. Studium o strukturze gatunkowej poematów Jana Kochanowskiego. Warszawa 2008, s. 21. Do pracy Krzywe go odsyłam skrótem K. Poza nim stosuję jeszcze oznaczenie O = W. J. Ong, Oralność i piśmienność. Stowo poddane technologii. Przekł., wstęp J. J a pola. Lublin 1992. Liczby po skrótach wskazują numery stronic.

4 Zob. J. Zi o m e k, O „Zuzannie” Jana Kochanowskiego. W zb.: Ze studiów nad literatura staropolska. Red. K. Budzy k. Wrocław 1957, s. 117.

5 Ibidem, s. 118-119. Dodatki greckie do Księgi Daniela - m.in. historia o Zuzannie i starcach - sa w protestanckich wydaniach Biblii pomijane (bo przez wyznania reformowane uważane są za apokryficzne). Katolicy zaś określają te fragmenty księgi jako deuterokanoniczne. Zob. M. P a r c h e m, Zagadnienia wstępne. W: Księga Daniela. Wstęp, przekł. z oryginału, koment. ... Częstochowa 2008, s. 33.

6 Określenia: „kalwinistka”, „kalwinizm”, nie funkcjonowały w ówczesnym społeczeństwie. Wyznawcy ewangelizmu reformowanego nazywali siebie w tym czasie raczej po prostu „ewangelika- 
Kochanowski podją tu grę $\mathrm{z}$ jednej strony $\mathrm{z}$ konwencjami występującymi w literaturze łacińskojęzycznej, a $z$ drugiej - z konwencjami właściwymi twórczości kręgu wernakularnego, ustnej oraz pisanej. Trzeba zatem przypomnieć tezę zawartą w rozważaniach Tadeusza Sinki, który stwierdził:

Czyniąc zadość prośbie żony Mikołaja Radziwiłła Czarnego, [Kochanowski] opowiedział jej biblijną opowieść o Zuzannie [...] jako przykład Opatrzności Boskiej nad ludźmi dobrymi. I sam wybór tematu [...], i styl, nawiązujący do tradycji rymowanych legend średniowiecznych, wypłynął z chęci przystosowania się do gustu adresatki ${ }^{7}$.

Podobieństwo Zuzanny do „pieśni dawniejszych” zauważył również Julian Krzyżanowski. Widział je tak w stylu utworu, jak i w odwołaniu do „kategorii "exempla" i historyj”, pojawiającym się w prologu ${ }^{8}$.

Podejmując konstatację Sinki, że dzieło Kochanowskiego w znacznej mierze inspirowane było „rymowanymi legendami średniowiecznymi”, skupię się przede wszystkim na części „narracyjnej” utworu (od w. 23) oraz na występujących w niej zabiegach wprowadzających w tekst elementy „wtórnej” oralności ${ }^{9}$. Kwestie pojawiające się przy analizie prologu dzieła natomiast tylko zarysuję, pominę zaś uwagi dotyczące części dedykacyjnej.

\section{Kobiety jako odbiorczynie literatury wernakularnej}

Kobiety w średniowieczu oraz wczesnej nowożytności odseparowane były od łaciny - języka, którego uczono chłopców (zob. O 155). Nie miały zatem możliwości zapoznawania się $\mathbf{z}$ rzymską tradycją literacką. Jednakże nieznajomość łaciny nie musiała oznaczać braku wykształcenia. Według Herberta Grundmanna część średniowiecznej szlachty europejskiej była dobrze wyedukowana, uczestniczyła wszakże w kulturze „śpiewanej i mówionej”, nie zaś w kulturze czytania i pisania. Edukacja, którą zyskiwano dzięki przynależności do kręgu kultury oralnej, stanowiła zatem, zgodnie z myślą Grundmanna, istotny składnik ogólnego wykształcenia ówczesnych elit ${ }^{10}$. Franz H. Bäuml podkreślał jednak, iż w Europie w ciągu

mi”. O konfesji Radziwiłłowej zob. D. C h e m p e r e k, „Kalwińska święta”. Elżbiety z Szydłowieckich Radziwiłłowej ars bene vivendi $w$ „Krótkim wypisaniu sprawy” Cypriana Bazylika. W zb.: Ars bene vivendi. Studia ofiarowane Profesorowi Maciejowi Włodarskiemu w 70. rocznice urodzin. Red. E. Buszewicz, L. Grzybowska. Kraków 2017, s. 275-277.

7 T. Sinko, wstęp w: J. Kochanowski, Pieśni i wybór innych wierszy. Oprac. T. Sinko. Wyd. 2, przejrz. Wrocław 1948, s. XXIII. BN I 100. W artykule więc podjęta jest dyskusja m.in. z Zi o m ki em ( $O$ „Zuzannie” Jana Kochanowskiego, s. 117), który uznał, iż sądy Sinki są „niesłuszne i fałszywe".

8 J. Krzyżanowski, Romans polski wieku XVI. Warszawa 1962, s. 185. Zob. też J. Krzyż a n ow s k i, Poezja polska wieku XVI. W: W wieku Reja i Stańczyka. Szkice z dziejów odrodzenia $w$ Polsce. Warszawa 1958, s. 47.

9 Podstawą rozumienia problematyki oralności w artykule jest praca O n g a (O). Korzystam również $\mathrm{z}$ ujęcia F. H. B ä u mla (Varieties and Consequences of Medieval Literacy and Illiteracy. „Speculum" 1980, $\mathrm{nr}$ 2).

10 H. Grundmann, Litteratus-illitteratus. Der Wandel einer Bildungsnorm vom Altertum zum Mittelalter. „Archiv für Kulturgeschichte” 1958, s. 18. Rozważania Grundmanna przytaczam za Bä u mlem (op. cit., s. 242), który polemizował jednakże $z$ omawianą tezą, określając ją jako 
stuleci coraz ważniejsza stawała się umiejętność pisania, analfabetyzm zaś odcinał od kultury, której przekaźnik stanowiło pismo. Istniała wobec tego potrzeba stałego kontaktu ze słowem pisanym, czy to w drodze zdobycia i udoskonalenia kompetencji posługiwania się nim, czy też poprzez wykorzystywanie umiejętności innych piśmiennych osób ${ }^{11}$. Chcąc być uczestniczkami kultury, kobiety musiały uzyskać dostęp do słowa pisanego. Wobec nieznajomości łaciny stawały się odbiorczyniami (i twórczyniami) tylko piśmiennictwa w językach narodowych (zob. O 210). M.in. $z$ tego powodu pojawiały się przekłady tekstów na jezzyki wernakularne ${ }^{12}$. Arystokratki oraz szlachcianki umiejące czytać i pisać w języku narodowym, jak się przyjmuje, nierzadko wspierały tłumaczenia dzieł na języki wernakularne ${ }^{13}$. Przykładami kobiecego patronatu nad przekładami na polski są średniowieczne teksty religijne: Psałterz św. Kingi czy Biblia królowej Zofii. Egzemplifikacją tego zjawiska może być również praktyka pisania panegiryków w dwóch językach; zazwyczaj łaciński utwór dedykowany był mężczyźnie, polski zaś - niewieście (często jego żonie) ${ }^{14}$. W średniowieczu i we wczesnej nowożytności zamożne przedstawicielki płci pięknej, chcąc uczestniczyć w życiu kulturalnym epoki, zostawały również opiekunkami artystów, wspierając ich dzięki swojemu majątkowi, przy czym mecenat kobiet skupiał się głównie na literaturze, pozostawiając męskim patronom takie dziedziny, jak choćby architektura ${ }^{15}$. Arystokratki i szlachcianki były wówczas nie tylko mecenaskami, lecz także czytelniczkami rodzimej literatury: poematów dydaktycznych, tekstów religijnych ${ }^{16}$, czy też twórczości świeckiej (przykładowo można tu wymienić świadczący o tym fragment przedmowy Hieronima Wietora, wydawcy Rozmów, które miat król Salomon madry z Marchołtem grubym a sprośnym, dzieła Jana z Koszyczek, które - według dzisiejszych kryteriów kulturowych - nie stroniło od dosadności ${ }^{17}$ ).

Zuzanna, dedykowana księżnej Radziwiłłowej, zdaje się zatem przystawać do horyzontu literackiego adresatki utworu, która znała zapewne teksty tworzone w rodzimym języku, a wśród nich prawdopodobnie również wernakularne pieśni hagiograficzne o proweniencji średniowiecznej, żywotne jeszcze w kulturze

anachroniczną, ponieważ „ustna poezja” zaczęła przyjmować formę pisana już w XII wieku (zob. ibidem, s. 242-243, zwłaszcza przypis 14).

11 Zob. Bä u ml, op. cit., s. 242 n.

12 Zob. R. Grześ k ow i a k, „Zwyczajem kawalerów ziemskich postępuje z nią Oblubieniec”. Pierwotna dedykacja „Pobożnych pragnień” Aleksandra Teodora Lackiego jako autorski projekt lektury emblematów Hermana Hugona. „Pamiętnik Literacki” 2015, z. 1, s. 208.

13 Zob. E. A u e r b a c h, Język literacki i jego odbiorcy $w$ późnym antyku łacińskim $i$ średniowieczu. Przeł. R. U rb ań s ki. Kraków 2006, s. 261. O kobietach jako odbiorczyniach literatury w jezzyku polskim pisał także Grześ kowiak (op. cit., s. 208-213).

14 Zob. J. Ni e dźw i e d ź, Nieśmiertelne teatra sławy. Teoria i praktyka twórczości panegirycznej na Litwie $w$ XVII-XVIII $w$. Kraków 2003, s. 204.

15 Zob. M. B o g u cka, Gorsza płeć. Kobieta $w$ dziejach Europy od antyku po wiek XXI. Warszawa 2005, s. 220.

16 Zob. Grześkowiak, op. cit., s. 209.

17 Rozmowy, które miał król Salomon madry z Marchołtem grubym a sprosnym. W zb.: Proza polska wczesnego Renesansu. 1510-1550. Oprac., wstęp, przypisy J. Krzyża now s ki. Wyd. 2. Warszawa 1954, s. 85-86. Zob. szerzej W. W oj t o w i c z, Między literatura a kultura. Studia o "literaturze mieszczańskiej” przełomu XVI i XVII wieku. Szczecin 2012, s. 253. 
polskiej w następnych stuleciach. Być może, w celu dostosowania dzieła do świadomości literackiej księżnej Kochanowski imitował „oralne” cechy treściowe i formalne, charakterystyczne dla tego gatunku. Oralność ta nie jest jednakże „pierwotna”, lecz „wtórna”, tzn. świadomie wprowadzona przez autora do dzieła literackiego ${ }^{18}$.

\section{Wersyfikacja i rymy „legend średniowiecznych” a Zuzanna}

Formalne cechy Zuzanny zbliżają tekst do legend hagiograficznych. Styl dzieła Kochanowskiego służy archaizacji utworu. Długość wersów zmienia się: z 13-zgłoskowca w dedykacji na asymetryczny 14-zgłoskowiec trocheiczny w części narracyjnej ${ }^{19}$. W dziele Kochanowskiego 14-zgłoskowiec jest zbudowany $\mathrm{z}$ segmentów 8- i 6-sylabowych ${ }^{20}$. Zauważył to już Krzyżanowski, pisząc, że poeta: „Zachował [...] w Zuzannie staroświecko pobrzmiewający rytm pieśni dawniejszych, przydługi wiersz czternastozgłoskowy [...]"21. Ten rozmiar wersów nadaje utworowi właśnie cechy tekstów archaicznych, choć pojawiał się w literaturze staropolskiej niezmiernie rzadko ${ }^{22}$. W Zuzannie, utworze stychicznym o układzie rymów aabb (z częstymi rymami gramatycznymi) ${ }^{23}$, granice zdań pokrywają się $z$ podziałem na wersy (wyjątek stanowią nieliczne przypadki zastosowania przerzutni) ${ }^{24}$. Cechą charakterystyczną polskiej poezji średniowiecznej było również występowanie utworów stychicznych, w których wersy zbudowane były ze zdań pojedynczych lub zdan składowych, stanowiących części wypowiedzenia złożonego ${ }^{25}$. Wiersz Zuzanny upodabnia do średniowiecznej pieśni hagiograficznej zdaniowy charakter wersów.

Teoretyczne rozróżnienie tych dwóch rodzajów oralności i wykorzystanie ustalonej terminologii do badania twórczości Kochanowskiego omawia w swoim artykule K. D a ta (Oralność tekstów Jana Kochanowskiego. „Quaestiones Oralitatis” 2015, nr 2, s. 85-89); nie wspomina jednakże o Zuzannie.

19 B. Łopatkówna (Czternastozgłoskowiec. W zb.: Sylabizm. Red. Z. Ko pczyń ska, M. R. Mayenowa. Wrocław 1956, s. 430) uznała, że Zuzanna jest najdłuższym polskim utworem epickim, ,jaki został napisany 14-zgłoskowcem sylabicznym w ogóle”. O długości wersu w Zuzannie wspominała również L. Pszczołowska (Wiersz polski. Zarys historyczny. Wyd. 2, popr. i uzup. Wrocław 2001, s. 61).

Takiego samego wersu wcześniej użył M. Rej w Żywocie Józefa (zob. K. W. Zaw o d ziń s ki, Studia $\mathrm{z}$ wersyfikacji polskiej. Oprac. J. B u d k ow s ka. Wrocław 1954, s. 169).

Kr zy ża now s ki, Romans polski wieku XIV, s. 185.

O rozmiarach wersów w tekstach średniowiecznych i renesansowych zob. J. W o r o n c za k, Elementy średniowieczne $w$ wersyfikacji polskiej XVI wieku i ich przemiany. W: Studia o literaturze średniowiecza i renesansu. Wrocław 1993, s. 173-173, 177-180, 182-183. Z wersami 14-zgłoskowymi spotkać się można także w strofice średniowiecznej poezji religijnej (Ł o p a t k ó w n a, op. cit., s. 427-428).

23 Kochanowski w swojej praktyce twórczej nie unikał rymów gramatycznych. Stosował je w różnych celach, np. dla uzyskania stylizacji melicznej dzieła (zob. P s z c z oł ow s ka, op. cit., s. 66). W Zuzannie poeta mógł wykorzystać taki typ rymów właśnie po to, by uzyskać archaizację brzmienia i upodobnić tym samym tekst do legend hagiograficznych.

24 W większości swoich utworów Kochanowski zerwał ze stosowaniem wiersza składniowego, używając przerzutni (ibidem, s. 68).

Zob. ibidem, s. 11-12. Zob. też L. Ps z c z ołow s ka, Rym. Wrocław 1972, s. 84-86. 


\section{„Kto nie ma nic pilniejszego, niech posłucha mało”. Prolog Zuzanny wobec tradycji}

Podjęta przez Kochanowskiego konwencję hagiograficznej pieśni wernakularnej zauważyć można już w prologu. Ma on dwie części, pierwsza z nich to prologus praeter rem:

Niechaj się źli nie kochają w swojej wszeteczności!
Żywie Bóg na niebie, który karze ludzkie złości,
A dobre ma na swej pieczy i każdego broni,
Kto się jeno pod zwyciężna Jego rękę skłoni.
Wielką moc takich przykładów w historyjach mamy
I sami tego na oko często doznawamy; [w. 13-18] ${ }^{26}$

Zwykle - i nie inaczej się dzieje w Zuzannie - w części tej nadawca stara się nawiązać kontakt $z$ odbiorcami poprzez podjęcie rozważań na tematy ogólne ${ }^{27}$. Zawarte tu zostały przemyślenia dotyczace dobra i zła oraz ich konsekwencji. Bóg ukazany jest jako gwarant sprawiedliwości na świecie: karze on niegodziwych, nad prawymi zaś czuwa. Przesłanie początkowego fragmentu prologu stanie się także myślą rozwijaną w dalszym ciągu utworu ${ }^{28}$.

Kolejna część - prologus ante rem - zgodnie z tradycją przedstawia temat dzieła, zawiera też często szczegółowe informacje o autorze, bohaterze i źródle tekstu ${ }^{29}$. W poemacie Kochanowskiego funkcję tę pełnią wersy:

Ale jesli kiedy znaczniej swój sąd Pan objawił,

Nigdy znaczniej, jako kiedy Zuzannę wybawił.

Kto nie ma nic pilniejszego, niech posłucha mało,

A ja powiem dostatecznie, jako się co zstało. [w. 19-22]

Opowiadający wprowadza w tych wersach postać Zuzanny, której los służy jako przykład sprawiedliwości Boskich wyroków. Podkreślony zostaje wyjątkowy charakter historii bohaterki biblijnej - wszak Pan „nigdy znaczniej” nie objawił swojej mocy niż wtedy, gdy „Zuzannę wybawił”. Owa doniosłość opisywanej sytuacji przyciągać ma uwagę czytelnika (attentio) - jest to niezwykle istotne zadanie, które ma

W swojej pracy korzystam z edycji: J. Ko c ha n ow s ki, Zuzanna. W: Dzieła polskie, t. 1. Cytując utwór, numery wersów podawać będę w nawiasach.

Zob. J. A. Schultz, Classical Rhetoric, Medieval Poetics, and the Medieval Vernacular Prologue. „Speculum” 1984, nr 1, s. 13. O częściach składowych prologu - czyli o prologus praeter rem i prologus ante rem - w kontekście średniowiecznej wernakularnej hagiografii pisał W. Wojtowicz (Prolog „Legendy o św. Aleksym”. „Pamiętnik Literacki” 2006, z. 3).

Pogląd ten jest powszechnie przyjęty przez badaczy. Ich wnioski różnią się głównie stosowaną terminologia. K. Ku pis z (Dwie „Zuzanny“ - wokót poematu biblijnego. „Prace Polonistyczne” 1987, s. 11) sądził, że w utworze pojawia się teza (prolog) wraz z następującym po niej exemplum. Kr zywy uznał, iż po wskazaniu w prologu „budującej intencji”, historia Zuzanny potraktowana zostaje jako egzemplifikacja „Bożej ekonomii” (K 22. Zob. też Ku pisz, loc. cit.). K. Ziemba („Zuzanna” i gatunki. W zb.: Wyobraźnia epok dawnych. Obrazy - tematy - idee. Materiały sesji dedykowanej Profesorom Jadwidze i Edmundowi Kotarskim. Red. J. K. Golińs ki. Bydgoszcz 2001, s. 115) stwierdziła zaś, że całe dzieło jest przykładem, który rozwija tezę zawartą w jego wstępie.

29 Zob. Schultz, op. cit., s. 13. Tam również dyskusja na temat takiego podziału średniowiecznych prologów (ibidem, s. 13-14). 
do spełnienia prolog utworu ${ }^{30}$. Końcówka prologu (w. 21-22) zawiera formułę oralną: ,ja opowiem, wy słuchajcie”, często występującą w literaturze średniowiecznej ${ }^{31}$. Formuła ta szybko stała się zwyczajowa, przechodząc $z$ twórczości oralnej do pisanej - by imitować ustne wykonanie dzieła.

Kochanowski, pisząc owe wersy, świadomie zastosował typowo oralne środki wyrazu. Aby zaobserwować podjęta przez autora konwencję pieśni hagiograficznych, porównać można prolog Zuzanny z prologiem średniowiecznej Legendy o świętym Aleksym. Wtedy zauważalna stanie się tożsamość tradycji, z której wywodzą się oba teksty (w przypadku Zuzanny konwencja ta jest wyłącznie imitowana). W Legendzie o świętym Aleksym pojawiają się dwie części prologu: prologus praeter rem, w którym osoba mówiąca w utworze zwraca się do Mesjasza z prośbą o dar natchnienia (w. 1-6), a po nim prologus ante rem:

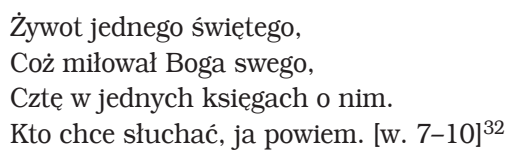

To właśnie w tym fragmencie wprowadza się do utworu postać św. Aleksego (podobnie jak Zuzannę w w. 19-22 dzieła Kochanowskiego); podkreślona zostaje też ważność przedstawionej treści - poprzez formułę oralną: „Kto chce słuchać, ja opowiem”, oraz poprzez samo przedstawienie świętego, który „miłował Boga swego"33. Paralelne występowanie w obu tekstach owych segmentów: części prezentującej bohatera, a także drugiej, zawierającej wezwanie do słuchania utworu, wskazuje na wykorzystanie podobnej tradycji.

\section{„Ale ogień, co go dusisz, to się barziej żarzy”. Dilatatio materiae}

Utwór Kochanowskiego nie jest - by posłużyć się słowami Romana Krzywego - „poematem programowo niekunsztownym" (K 21). Czarnoleski poeta czerpał inspirację z różnych źródeł ${ }^{34}$. Zastosował np. zabieg zwany dilatatio materiae, wzbogacając swój utwór o nowe treści, nie występujące w historii biblijnej ${ }^{35}$. To pozwalało poecie

Zob. Woj tow i c z, Prolog „Legendy o św. Aleksym”, s. 162.

Zob. T. M i c h ało w s ka, Między słowem mówionym a pisanym. O poezji polskiej późnego średniowiecza. W zb.: Literatura i kultura późnego średniowiecza $w$ Polsce. Red. ... Warszawa 1993, s. $96-100$.

Fragmenty z Legendy o świętym Aleksym pochodzą z edycji zamieszczonej w: W. Wydra, W. R. Rze pka, Chrestomatia staropolska. Teksty do roku 1543. Wrocław 1984. Cytując utwór, podawać będę numery wersów w nawiasach.

Zob. W oj t o w i c z, Prolog „Legendy o św. Aleksym”, s. 165. Autor artykułu wskazuje, że podobna formuła występuje także na początku Pieśni o świętym Jopie: „Ten Boga wiernie miłował” (Polskie wierszowane legendy średniowieczne. Wyd., oprac. S. Wi erczyńs ki, W. Ku raszki ewicz, ze współudz. A. Sła w ski j. Wrocław 1962, s. 251, w. 9. BPP, A 2).

Przykładowo: Zi e mb a (op. cit., s. 114-115) wysnuła tezę mówiącą, że Zuzanna wraz z pieśnią Czego chcesz od nas, Panie, za Twe hojne dary... przejawia cechy struktury psalmu.

$\mathrm{W}$ tym kontekście wskazuje się także na inspiracje XV-wiecznym włoskim utworem La istoria della casta Susanna autorstwa florenckiej poetki L. To r n a b u on i. Według B. A w i a n ow i c za („La istoria Della casta Susanna” Lucrezii Tornabuoni - możliwe źródło „Zuzanny” Jana Kochanow- 
uatrakcyjnić tekst hagiograficzny, a jednocześnie przekonać czytelników o własnej uczoności i wysokiej kulturze literackiej ${ }^{36}$.

Autor Zuzanny mógł zatem swobodnie dysponować materiałem biblijnej opowieści, skracając albo rozszerzając ją o dowolne wątki. Narracja ta, utrwalona w świadomości twórcy oraz odbiorców, mimo owych przekształcen, pochodzących z literatury teologicznej, hagiograficznej czy świeckiej, nie była zasadniczo (w okresie przedreformacyjnym) poddawana krytyce w zakresie prawdziwości lub fałszu. Nie analizowano znaczenia poszczególnych, amplifikowanych elementów ${ }^{37}$. Kochanowski (odnosząc się do przedreformacyjnej praktyki) wzbogacił wobec tego biblijną historię Zuzanny treściami pochodzącymi tak z kultury świeckiej (nawiązania do literatury antycznej i rodzimej, do dworskiego języka), jak i z religijnej (np. z pieśni hagiograficznych). Postępując w tym duchu, Kochanowski nie narażał się na potępienie za przekształcanie „historii”, ponieważ jej wymowa pozostała niezmienna.

Egzemplifikację dilatatio materiae, występującego w Zuzannie, stanowić może w. 55: „Ale ogień, co go dusisz, to się barziej żarzy”. Pochodzi on z Metamorfoz Owidiusza (,quoque magis tegitur, tectus magis aestuat ignis" ${ }^{38}$ ) i dotyczy historii Pyrama i Tyzbe. Kolejne amplifikacje to w. 48, 52 i 56: „A komu kiedy zdradliwa miłość przepuściła?)”, „Obu miłość opętała i niebaczna sprawa”, „Co dzień więcej się dziwują onej pięknej twarzy”. Krzywy (K 26) wskazywał na ich gnomiczną naturę, Ziemba zaś zwracała uwagę (nie precyzując tego bliżej), że źródła ich odnaleźć można w rzymskiej elegii ${ }^{39}$. Owe wplecione w tekst fragmenty o antycznej proweniencji rzeczywiście pełniły funkcję gnomicznych stwierdzeń. Gnomy, w przeciwieństwie do potocznych przysłów, charakteryzowały się niezwykle dopracowanym kształtem, czyniacym z nich niemal samodzielne, miniaturowe „dziełka” literackie ${ }^{40}$. Użycie takich konstrukcji świadczyć miało o erudycji autora - jak piszą Jadwiga Czerwińska i Magdalena Koźluk:

W szesnastym wieku forma gnomiczna stała się wymogiem formalnym w tekstach pisanych i mówionych. Zalecana przez wszystkie XVI-wieczne retoryki ze względu na zwięzłą formę (brevitas), powagę (auctoritas) stanowiła również niezbity dowód retorycznego przygotowania mówcy (eloquentia) $[\ldots]^{41}$.

skiego. „Europa Orientalis” 2016) pomysły na amplifikacje Kochanowski czerpać miał właśnie ze wspomnianego dzieła.

Zob. E. F e is t n e r, Historische Typologie der deutschen Heiligenlegende des Mittelalters von der Mitte des 12. Jahrhunderts bis zur Reformation. Wiesbaden 1995, s. 354 n. Cyt. za: W. W o j tow i c z, Tradycje tekstu staropolskiej „Legendy o świętym Aleksym”. Kilka uwag. „Wiener Slavistisches Jahrbuch" 2004, s. 125.

37 Zob. ibidem.

38 P. Ovidii Na sonis Metamorphoses. Ed. W. S. Ander s on. Wyd. 3. Leipzig 1985, s. 79 (IV 64). Zob. K 26.

39 Zi iemba, op. cit., s. 118-119.

40 Zob. M. Stuligrosz, Gnoma: definicje i zakres zastosowania. „Symbolae Philologorum Posnaniensium Graecae et Latinae" t. 11 (1997), s. 42.

41 Zob. J. C z e rw iń s ka, M. Ko źlu k, „Quicquid in Euripide, tragicorum principe, memorabile est” - forma gnomiczna Eurypidesa oraz jej recepcja w XVI wieku. Jw., t. 18 (2008), s. 109. Zob. też s. $109-111$. 
Badaczki te wspomniały również o źródłach, $\mathrm{z}$ których gnomiczne fragmenty czerpali XV-wieczni literaci:

Badania Ann Moss wykazały, że przeciętny humanista, ćwicząc się w redakcji tekstów, już w młodzieńczym wieku dysponował solidną bazą retoryczno-gnomiczną, nabytą podczas edukacji szkolnej. Sentencje i przysłowia różnych auctores czerpał on nie tylko $\mathrm{z}$ ukazujących się stopniowo editiones principes, ale przede wszystkim $\mathrm{z}$ różnych zbiorów loci communes, bardzo popularnych w okresie renesansu. Układane tematycznie sentencje dotykały różnych sfer życia i służyły zgłębianiu mechanizmów dialektyki i retoryki. [...] na uwagę zasługiwały specjalnie przygotowywane i cieszące się dużym uznaniem od początku XVI wieku podręczniki mnemotechniczne, $z$ których można było zapożyczyć sententiae selectae autorów według wybranych kryteriów: języka, kategorii, autora (Publius Syrius, Ovidius), grupy autorów lub tematów i toposów (De prudentia, De virtute, De fuga, De audacia) ${ }^{42}$.

Stosowanie sentencji w dziełach dawało humanistom wiele korzyści: podkreślało ich wysoką kulturę słowa i zdolność do twórczej imitacji mistrzów. Jednocześnie wkomponowane w tekst gnomiczne wyrażenia służyły nierzadko wzmacnianiu przeprowadzanej w nim argumentacji ${ }^{43}$. Kochanowski, używając literackich sentencji (w tym jednej pochodzącej z klasycznego dzieła Owidiusza), dawał dowód swego retorycznego przygotowania, elokwencji. W taki sposób połączył w Zuzannie tradycyjną kulturę wernakularną ze świadomością poetycką autora renesansowego.

Wskazując u Kochanowskiego inspiracje poezją dworską, wspomnieć trzeba o wypowiedzi starców, skierowanej do bohaterki:

Nie lękaj się, piękna pani, sługi swoje widzisz,

Za które się nigdy, da Bóg, sprawnie nie powstydzisz;

Jedno nam nie chciej być trudna, którzy cię miłujem,

A dla ciebie niewymowną w sercu boleść czujem.

Czas po temu masz i miejsce, drzwi zawarte stoja,

Żywy człowiek nas nie widzi, pomóż łaską swoją. [w. 73-78]

Przytoczony fragment zawiera cechy wytwornego języka miłości. Starcy zwracają się w nim do Zuzanny jako do „swojej pani”, mogącej obdarzyć ich „łaską”. Jest to modyfikacja w stosunku do wersji biblijnej, w której żądają oni, by żona Joakima z nimi współżyła: „Oto drzwi sadu są zamknione, a nikt nas nie widzi, a my w pożądliwości twojej jesteśmy: przetoż przyzwól nam a śpi z nami” (Dn 13, 20) ${ }^{44}$. Kochanowski w swojej wersji historii łagodzi jednakże wydźwięk tych słów, używając

Ibidem, s. 110. Wspomniana praca A. M os s to Printed Commonplace-Books and the Structuring of Renaissance Thought (Oxford 1996). Autorki cytowanego artykułu korzystały z francuskiego przekładu tej książki: Les Recueils de lieux communs. Méthode pour apprendre à penser à la Renaissance. Trad. P. Eichel-Lojkine, M. Lojkine-Morelec, (M.-Ch. Munoz-Teulié), G.-L. Tin. Sous la dir. de P. Ei c hel-L oj k in e. Genève 2002, rozdz. 6: Le Recueil de lieux communs à l'école.

43 Zob. Czerwińska, Koźluk, op. cit., s. 111.

44 Cytaty z Biblii pochodzą z edycji: Biblia w przekładzie księdza Jakuba Wujka z 1599 r. Transkrypcja typu „B” oryginalnego tekstu z XVI w. i wstępy ks. J. F r a n k ow s ki. Wyd. 8. Warszawa 2013. Ponieważ tłumaczenia polskie osłabiają nieco stanowczość cechującą żądanie starców, warto sięgnąc po wersję łacińską (Biblia sacra. Iuxta Vulgata versionem adiuvantibus B. Fis cher, I. Gribomont, H. F. D. Sparks, W. Thiele. Recensuit et brevi apparatu critico instruxit R. Weber. Ed. 5. emendatam rectactatam praeparavit R. Grys on. Stuttgart 2007, s. 1369): „ecce ostia pomerii clausa sunt et nemo nos videt et in concupiscentia tui sumus quam ob rem ad- 
języka dworskiego. Choć literatura XVI-wieczna nie stroniła od ujęć erotyzmu przepełnionych agresją ${ }^{45}$, czarnoleski poeta zdecydował się przemodelować ów fragment, być może, właśnie ze względu na adresatkę tekstu (nie zmieniając jednocześnie rodzaju propozycji złożonej Zuzannie). Elżbieta z Szydłowieckich Radziwiłłowa, córka kanclerza wielkiego koronnego, znała zapewne ten sposób wypowiadania się, stosowany na dworach arystokratów, dlatego też przekształcenie to sprawiło, iż utwór bardziej wpasowywał się w charakter jej doświadczeń kulturowych ${ }^{46}$. Poeta, używając dworskiego języka (pod którego warstwą - szczególnie w twórczości trubadurów - skrywało się erotyczne niespełnienie ${ }^{47}$ ), skontrastował tę wysublimowaną wypowiedź antagonistów Zuzanny z biblijną bezpośredniością ich prośby (czy raczej żądania). Przez nazwanie zaś aktu seksualnego „łaską, Kochanowski złączył zapewne jezzyk erotyczny z językiem religijnym - gdyż słowo to wzbudzać mogło w czytelniku skojarzenia z łaską Bożą ${ }^{48}$. Wprowadzając kolejną modyfikację, poeta podjął więc zabawę z konwencją dworskiej miłości.

O sięganiu przez Kochanowskiego do różnych źródeł w celu wzbogacenia opisywanej historii świadczą też zbieżności fragmentów, które występują tak w Żywocie Józefa Mikołaja Reja, jak i w (późniejszej) Zuzannie. Pierwsze podobieństwo uwidacznia się już w konfrontacji dwuwiersza z prologu: „Żywie Bóg na niebie, który karze ludzkie złości, / A dobre ma na swej pieczy i każdego broni,", z wersami pochodzącymi $z$ utworu Reja:

\author{
Żyw ten Pan Bóg na niebie, \\ który w to ugadza, \\ Iż każdemu prawemu \\ sowito nagradza,
}

sentire nobis et commiscere nobiscum". Zob. komentarz do wypowiedzi starców: Księga Daniela, s. 713.

45 Zob. J. C. B ologn e, Historia uwodzenia. Od antyku do dziś. Przeł. K. M a r c ze w s ka. Warszawa 2012, s. 133.

46 Zob. J. Huizinga, Jesień średniowiecza. Przeł. T. Brzostowski. Wstęp H. B ary cz. Posł. S. Her b st. Warszawa 1992, rozdz. Stylizacja miłości). Panie z dworów, arystokratki, mogły być obiektami wyrafinowanych zalotów - inaczej bowiem traktowano kobiety z niższych warstw. Zob. B o log n e, op. cit., s. 74: „przyznając szacunek wyłącznie kobietom, które uznawała za godne czci, miłość dworska usprawiedliwiała wszelkie okrucieństwo i grubiaństwo wobec dziewcząt nie zasługujących na jej względy".

47 Zob. Huizinga, op. cit., s. 135. O zależnościach pomiędzy umiejętnością hamowania popędów a powstawaniem „dwornych form towarzyskich”, w tym kurtuazji w stosunku do kobiet, pisał w rozdziale Socjogeneza liryki trubadurów i dwornych form towarzyskich N. E li a s w pracy O procesie cywilizacji. Analizy socjo- i psychogenetyczne (Przeł. T. Zabł u d o w s ki, K. M a r ki e w i c z. Warszawa 2011).

48 O nawiązaniach religijnych w dworskim języku miłości pisał m.in. D. de Rougemont (Miłość a świat kultury zachodniej. Przeł. L. E u s t a c h i e w i c z. Wyd. 2. Warszawa 1999, s. 58-59, 77-78). Słowo „łaska” miało w czasach Kochanowskiego dwa znaczenia (zob. L. W o r o n c z a k o w a, Łaska. Hasło w: Stownik polszczyzny XVI wieku. T. 12. Red. M. R. Ma y e n ow a. Wrocław 1979, s. 479, 484, 489). Pierwsze z nich to życzliwość okazywana przez osobę będącą wyżej w hierarchii społecznej osobie znajdującej się niżej (jako przykład odnotowano tu użycie tego wyrazu w Zuzannie); natomiast drugie „nadprzyrodzony wewnętrzny dar życiowy udzielany ludziom przez miłość Bożą, aby mogli oni uczestniczyć [...] w życiu wiecznym”. Słowo „łaska” występujące w Zuzannie może zatem mieć konotacje religijne. 
Iż mię acz na czas karze według swojej wolej,

Lecz nadstawi swoboda

tej mojej niewolej. [w. 3314-3321] ${ }^{49}$

Zgodność myśli, a także warstwy formalnej (w tym użycie rymu opartego na współbrzmieniu analogicznych słów) pojawia się też w chwilach, gdy bohaterowie obu historii zostaja postawieni w obliczu dylematów moralnych. Zuzanna (po propozycji złożonej jej przez starców) stwierdza: „Ale wolę bez winności od waszych rąk zginąć / Niż przed Bogiem i przed ludźmi niecnotliwą słynąć” (w. 93-93). Podobne słowa w konfrontacji z żoną Putyfara wypowiada Józef:

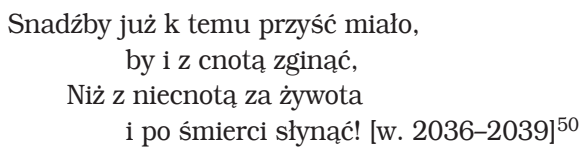

Wspólne cechy w niektórych fragmentach tekstu oraz zbliżona wymowa obu dzieł świadczyć mogą o inspirowaniu się przez Kochanowskiego Żywotem Józefa, a co za tym idzie - o kalwińskich wpływach występujących w Zuzannie ${ }^{51}$, lub o wspólnocie tradycji literackiej, z której czerpali obaj poeci ${ }^{52}$.

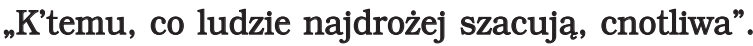 Kategoria cnoty w Zuzannie}

Kochanowski wprowadził amplifikację w stosunku do źródła biblijnego już w prezentacji bohaterki:

Ku dostatku tym go jeszcze fortuna zdobiła,

Że Zuzanna poślubioną jego żoną była:

Białagłowa dziwnie gładka, młoda, urodziwa,

K’temu, co ludzie najdrożej szacują, cnotliwa. [w. 29-32]

Fragment ten porównać można $\mathrm{z}$ wersetem z Proroctwa Danielowego: „I pojął żonę imieniem Zuzannę, córkę Helcjasza, barzo piękną i bojącą się Boga” (Dn 13, 2). Poeta dodał kolejne epitety do opisu bohaterki ${ }^{53}$, zgodnie $\mathrm{z}$ retoryczna zasadą za-

M. Rej, Żywot Józefa. W zb.: Dramaty biblijne XVI wieku. Oprac., wstęp, przypisy K. Wil c ze ws ka. Lublin 2000, s. 228.

Ibidem, s. 170.

O koncepcji cnoty w Żywocie Józefa pisał J. L. Maciuszko (Mikołaj Rej. Zapomniany teolog ewangelicki z XVI wieku. Warszawa 2002, s. 141-145). Jednakże badacze literatury nie są obecnie zgodni, czy utwór jest już wyrazem kalwińskich poglądów autora, czy też zawiera jeszcze spory ładunek myśli katolickiej (ibidem, s. 153-156).

52 Utwory wykazują również inne podobieństwa formalne: w Zuzannie pojawia się (rzadki w poezji polskiej) 14-zgłoskowiec asymetryczny (8+6), który wykorzystał w swoim dziele także Rej (zob. Zawo dzińs ki, op. cit., s. 169; zob. też Ło pat kówna, op. cit., s. 428, 430).

Zob. K 25: „Poeta renesansowy podąża tym śladem, zastępując jednak jeden epitet biblijny odnoszący się do urody dwoma i dodając również informację o wieku, a także wymieniając pobożność na cnotę (zatem kategorię o szerszym zakresie), o której wadze dla ludzi znajdziemy w utworze poboczną, lecz znamienna informację". Podkreślając te modyfikacje Kochanowskiego, badacz zdaje się nie zważać na zwyczaje wczesnonowożytnych (i wcześniejszych) twórców, dla których 
lecająca rozszerzanie (amplificatio) partii utworu, które pełnią funkcję opisowa

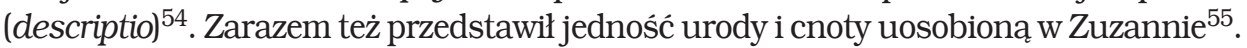

Trzeba zgodzić się z Krzywym, który zakwestionował tezę Jerzego Ziomka o laickości pojęcia cnoty w utworze czarnoleskiego poety ${ }^{56}$. W dalszym toku opowieści o Zuzannie uwidoczni się, iż wszelka motywacja działań kobiety pochodzi właśnie $z$ jej wiary w Boga i w jego potęgę. U Kochanowskiego w scenie rozmowy $z$ prześladowcami bohaterka stwierdza:

\author{
Zewsząd ucisk przyszedł na mię (niestetyż mnie, Panie!), \\ Bo jesli się dam namówić, za śmierć mi to stanie; \\ $Z$ drugiej strony, jesli zasię wam g'woli nie będę, \\ Jakobym na to patrzyła, że gardła pozbędę. \\ Ale wolę bez winności od waszych rąk zginąć \\ Niż przed Bogiem i przed ludźmi niecnotliwą słynąć. [w. 89-94]
}

Zarówno w tej wypowiedzi, jak i w tzw. „nocnej skardze” (w. 109-126), Zuzanna na pierwszy plan wysuwa problem cnoty i niesłusznego oskarżenia. Koncepcja cnoty jako drogi do Boga (nie zaś jako „samodzielnej”, najwyższej wartości), którą przedstawił w Zuzannie Kochanowski, zgadzała się z pojęciem cnoty zawartym w pracach XVII-wiecznych neostoików. Ich poglądy tak scharakteryzowała Estera Lasocińska:

Cnota w neostoicyzmie przybrała rolę środka, nie zaś samego celu [...]. To Bóg był i najwyższym dobrem, i prawdziwym szczęściem, cnota natomiast stawała się drogą do Niego. [...] Moralność, podobnie jak w starożytnym stoicyzmie, stała się w myśli neostoickiej warunkiem koniecznym szczęścia. Jednak nie była jego warunkiem wystarczającym ${ }^{57}$.

Nie mogąc ograniczać się tylko do ziemskiego, materialnego świata, cnota musiała ten wymiar przekraczać, szukając oparcia w Bogu ${ }^{58}$. Podobnie jak w przypadku bohaterki omawianego utworu, która nie odstępuje od swoich zasad właśnie

naturalne było wówczas przekształcanie „opracowywanego” pierwowzoru, dokonywanie amplifikacji, skrótów oraz szeroko rozumianych zmian. Rolę inwencji tłumacza w XVI-wiecznej praktyce translatorskiej na przykładzie m.in. dzieła Jana z Koszyczek Rozmowy, które miał król Salomon madry z Marchottem grubym a sprosnym zbadała Z. P od haj e ck a (Rozważania nad sytuacja przekładu artystycznego $w$ pierwszej fazie ery druku. Na materiale XVI-wiecznego romansu polskiego. „Pamiętnik Literacki” 1980, z. 1, s. 15-21).

54 Zob. P. Zu m th or, Retoryka średniowieczna. Przeł. J. Ar nold. „Pamiętnik Literacki” 1977, z. 1, s. 229. - E. R. Curtius, Literatura europejska i łacińskie średniowiecze. Przekł., oprac. A. B or owski. Wyd. 2, popr. Kraków 2005, s. 189-190.

O jedności urody i pobożności w opisie Zuzanny, a także innych postaci kobiecych występujących w Septuagincie pisał M. P a r c h e m w egzegezie wersetu 13, 2 biblijnego Opowiadania o Zuzannie (Księga Daniela, s. 707): „Zuzanna określona jest jako "bardzo piękna" i "bojąca się Pana", co uwydatnia zarówno jej piękno fizyczne, jak i duchowe. W podobny sposób charakteryzuje się w Biblii Greckiej inne kobiety, między innymi Judytę [...], Sarę, córkę Raguela [...] i Esterę [...]”.

K 25. Zi o m e k ( $O$ „Zuzannie” Jana Kochanowskiego, s. 131) stwierdził, iż w wersie 32 następuje „wyraźna zmiana motywacji religijnej na laicka”. Podobne zdanie miał W. Wale c ki (Motyw Zuzanny i starców $w$ literaturze staropolskiej. 〈Szkic zagadnienia〉. „Rocznik Komisji Historycznoliterackiej" 1972 , s. 45).

57 E. La s o c iń s ka, „Cnota sama z madrościa jest naszym żywotem”. Stoickie pojęcie cnoty $w$ poezji polskiej XVII wieku. Warszawa 2003, s. 70.

Zob. ibidem, s. 97. 
z powodu wiary w sprawiedliwość Boga. Ową virtus należałoby zatem (jeśli przyjąć w interpretacji kontekst kalwiński, związany z osobą adresatki) utożsamić $\mathrm{Z}$ wiara $\mathrm{w}$ Boga, a w koncepcji neostoickiej - $\mathrm{Z}$ drogą ku Niemu. Cnota w dziele Kochanowskiego nie stanowi więc wartości świeckiej.

Zuzanna od samego poczatku poematu przedstawiona zostaje jako kobieta cnotliwa, a właściwość ta będzie definiować cała jej postać (zob. K 27) - żywot jej dowieść ma przecież, iż pobożnych ludzi czeka nagroda. Przypisywanie bohaterom stałych cech (lub zespołów cech) wywodzi się z oralnych technik pamięci. W przypadku protagonistki analizowanego utworu cechę taką stanowi owa cnotliwość. Bohaterowie opowieści ustnych wyposażeni bywali w tzw. epitet stały, określający najistotniejszy (dla przebiegu fabuły) rys ich charakteru i pełniący zarazem funkcje mnemotechniczne ${ }^{59}$. W kręgu kultury ustnej postaci „płaskie” prezentowały się właśnie poprzez swoje (zazwyczaj spektakularne) czyny (Ong pisał: „Werbalizacja oralna i $z$ oralnym residuum zwraca uwagę na zdarzenia, a nie na wizualny wygląd przedmiotów, scen lub osób” 〈O 172; zob. też O 101-123, 201-205〉). Protagoniści utworów należących do tej tradycji często są wręcz tożsami ze swoimi działaniami ${ }^{60}$.

W scenie nocnej skargi Zuzanny uwidacznia się (wspomniana już w kontekście cytatu z Przemian Owidiusza) wysoka kultura literacka Kochanowskiego. Swój poemat wzbogaca on więc o elementy pochodzące $z$ dzieł klasycznych. Wypowiedź protagonistki utworu wzorowana jest bowiem na soliloquium ${ }^{61}$. Krzywy określa ów fragment nie tylko jako soliloquium, lecz dokładniej jako sermocinatio ${ }^{62}$. Jak wyjaśniał badacz, kwestie takie wygłaszane były zazwyczaj przez bohaterów przed jakimś kluczowym czynem lub przed decyzją, która przesądzić miała o całym przebiegu fabuły. Podczas przemowy protagonista ukazywał czytelnikowi najważniejsze dla siebie wartości (K 27).

Słowa bohaterki zatem mają charakteryzować jej wnętrze, przedstawić rozważania, które podjęła ona w obliczu niesłusznego oskarżenia. Dzięki przytoczonym myślom protagonistki poznać można także motywację jej działań (zob. K 27). Jacek Sokolski wskazuje, że następujące w wypowiedzi Zuzanny elementy: skarga na

Zob. O 102-103. To przyporządkowanie wybranej cechy osobie Krzywy nazwał retoryczno-epicką zasadą, polegającą na łączeniu opisywanej postaci „Z wartościami czy cnotami, w które autor zamierzał ją wyposażyć” (K 27). Nie sięgając w swojej rozprawie do oralnych konwencji podjętych przez Kochanowskiego, badacz wspomniał również o „odpowiednio nacechowanym działaniu” (K 27), pozwalającym czytelnikom poznać bohatera.

60 O utożsamianiu człowieka w społeczeństwie bohaterskim z jego czynami pisał A. Ma c Intyre (Dziedzictwo cnoty. Studium z teorii moralności. Przekł., wstęp, przypisy A. C h mi elew s ki. Przekł. przejrz. J. H ołó w ka. Warszawa 1996, s. 228), cytując opinię H. Fränkela: „człowiek [homerycki] i jego czyny stają się jednym i tym samym; można go całkowicie i poprawnie zrozumieć dzięki jego czynom, nie ma on żadnych ukrytych głębi... W 〈epickim〉 opisie ludzkich czynów i wypowiedzi wyraża się wszystko, czym ludzie są, ponieważ nie są oni niczym innym niż to, co robią, mówią i co znoszą".

61 Krzywy (K 27) wspomina o podobieństwie słów Zuzanny do fragmentów wypowiedzi bohatera dramatu Hyppolytos uwieńczony Eurypidesa. Badaczowi uwagę na ten fakt zwrócił J. Mańkowski.

62 Nie rozpoznając hagiograficznych konwencji (cechujących się oralnym residuum), Krzywy dostrzegł jednakże podobieństwo do epiki, która jest „niezmiennie formą sztuki oralnej” (O 209), i podążając tym tropem, stwierdził, iż forma nocnej skargi Zuzanny sięga tradycji eposów Homera (K 27). 
Fortunę oraz pochwała cnoty i Bożej sprawiedliwości, przypominaja konsolację zawarta w dziele Boecjusza O pocieszeniu, jakie daje filozofia ${ }^{63}$. Podczas gdy w tekście Kochanowskiego to Zuzanna jest postacią wygłaszająca i skargę, i pochwałę, $\mathrm{u}$ Boecjusza są one podzielone pomiędzy dwoje wypowiadających: narzekanie wychodzi $z$ ust postaci zwanej imieniem samego autora, pocieszania zaś udziela mu Filozofia ${ }^{64}$. Skarga Boecjusza na opatrzność Bożą, na to, iż cnota nie jest wynagrodzona (tylko nie dostrzegana przez Boga), a zbrodnia nie zostaje ukarana, spotyka się z kontrargumentacją Filozofii ${ }^{65}$, stwierdza ona, że błądzi ten, kto oczekuje nieprzerwanej przychylności Fortuny, ponieważ jest ona nieprzewidywalna, człowiek zaś musi pokornie znosić jej kapryśność ${ }^{66}$. Co więcej, ze zmienności losu można wyciągnąć wnioski i dzięki nieszczęściom doskonalić się w cnocie. Korzystając z tego powszechnie znanego traktatu Boecjusza, Kochanowski stworzył scenę, w której Zuzanna sama dokonuje konsolacji, przechodząc od skargi na niestałość Fortuny do pochwały sprawiedliwości Boga.

\section{"Białagłowa dziwnie gładka, młoda, urodziwa”. Zuzanna jako postać „ciężka”}

Cnotliwość Zuzanny Kochanowskiego jednocześnie łączy bohaterkę $z$ tradycją średniowiecznych pieśni hagiograficznych ${ }^{67}$, opowiadających o ludziach, którzy, tak jak np. św. Aleksy i św. Dorota, oddali swoje życie służbie Bogu. Zuzannę znamionują również wspomniane przez Onga cechy postaci „ciężkiej”, tzn. osoby, której „czyny mają charakter monumentalny, pamiętny i zazwyczaj publiczny” (O 102-103), stosownie do zasad działania oralnych procesów noetycznych ${ }^{68}$. W prologu do Zuzanny podkreślona jest także ważność czy niezwykłość losów protagonistki, szczególnie fakt Boskiej interwencji podczas sądu, dokonującej się dzięki obecności proroka Daniela: „Ale jesli kiedy znaczniej swój sąd Pan objawił / N ig d y z n a c zn i j, jako kiedy Zuzannę wybawił" (w. 19-20; podkreśl. D. V.). Przypadki podobnych cudownych ingerencji odnaleźć można w Legendzie o świętym Aleksym (dzwony, których dźwięk rozlega się po śmierci bohatera 〈w. 195-196, 212〉) ${ }^{69}$ czy też w Legendzie o świętej Dorocie (zjawienie się Boskiego posłańca, przynoszącego Teofilowi dary od straconej dziewicy〈w. 111-132〉). Zarówno wymienieni świę-

J. S o k ols ki, Bogini, pojęcie, demon. Fortuna $w$ dziełach autorów staropolskich. Wrocław 1996, s. 36-37. Badacz omyłkowo podaje, że nocna skarga Zuzanny mieści się w wersach 109-122, tymczasem właściwy zakres jest o 4 linijki dłuższy (do w. 126).

A. M. S. B o e cj u s z, O pocieszeniu, jakie daje filozofia. Przekł., oprac. G. K u ryle wi c z, M. An tczak. Przedm. A. Kijew ska. Kęty 2006, s. 110-111. - Sokolski, op. cit., s. 37.

Zob. A. Kij ew s k a, Boecjusz. Kraków 2011, s. 75 n.

Ibidem, s. 76-77.

T. M i c h ałow s ka (Bohater literacki-pojęcie. Hasło w: Słownik literatury staropolskiej. Średniowiecze - renesans - barok. Red. T. Michałowska, przy udz. B. Otwinowskiej, E. Sarnow ski j- Te m e ri u sz. Wrocław 1990, s. 102) stwierdziła, iż w hagiografii występuje bohater statyczny - typ świętego. Cały obraz jego życiowej drogi prowadzić miał do „radosnego powrotu do Boga”.

Zob. Bä u m l, op. cit., s. 248.

Zob. W. W oj t o w i c z, Między oralnościa a pismem. Kilka uwag o staropolskiej „Legendzie o św. Aleksym”. „Pamiętnik Literacki” 2006, z. 2, s. 187. 
ci, jak i Zuzanna wywodzili się ze znakomitych rodzin, słynących z bogactw, np. Aleksy pochodził $z$ rodu Eufamijana (w. 11-35), o Dorocie wspomniano, że „Teodora matką twą, [...] Krolewskiego jeś rodu była” (w. 13-16) ${ }^{70}$, Zuzanna zaś była małżonką Joachima, „człowieka dobrego żywota”, cieszącego się dostatkiem oraz przychylnością ludzi i losu (w. 27-30).

Krzywy, opisując omawiany utwór terminem „epika elegancka” (K 30), stwierdził, iż bohaterka z Księgi Daniela nie odpowiadała wymaganiom epiki „wysokiej”: „kobieta jako główna postać narracji poetyckiej rozmijała się ewidentnie z renesansowymi wyobrażeniami na temat epickiego protagonisty, którym winien być mężczyzna dokonujący jednego znakomitego czynu, przedstawionego w wysokim rejestrze stylistycznym” (K 22) ${ }^{71}$. Jeśli jednak przyjmie się hagiograficzną inspirację dzieła Kochanowskiego, Zuzanna jako postać pierwszoplanowa utworu nie dziwi. W żywotach pojawiają się wszakże zarówno święci mężowie, jak i niewiasty, np. wspomniana Dorota czy Kateřina z legendy staroczeskiej.

W Zuzannie uwidacznia się oralna zasada nieopisywania postaci niedziałających. Bohaterowie, którzy nie dokonują żadnych ważnych czynów, stawali się bowiem nadwyżką zbędną dla pamięci wykonawcy utworu, dlatego też redukowano ich obecność do minimum ${ }^{72}$. Ów element oralnego residuum odnaleźć można w średniowiecznej hagiografii - w Legendzie o świętej Dorocie czytelnik nie dowiaduje się żadnych szczegółów o rodzicach świętej, nie ma także nic o królu Fabrycyjuszu, który zapragnął ją poślubić (opatrzony on został tylko epitetem stałym - jest „krolem okrutnym" (w. 23, 34 )). Z tą swoistą ekonomią przekazu stykamy się w Zuzannie. Kochanowski, na wzór hagiograficznych pieśni, opisuje jedynie bohaterów ważnych, kluczowych dla rozwoju akcji. Usuwa wątki niepotrzebne mu w narracji, eliminuje również zbędne postaci. Zacytujmy dwie wersje początku historii o Zuzannie - z Biblii:

I był mąż mieszkający w Babilonie, a imię jego Joakim. I pojął żonę imieniem Zuzannę, córkę Helcjasza, barzo piękną i bojącą się Boga, bo rodzicy jej, będąc sprawiedliwi, wyćwiczyli córkę według Zakonu Mojżaszowego. A Joakim był barzo bogaty i miał sad podle domu swego, a do niego się Żydowie schodzili, iż był ze wszytkich najpoczciwszy. [Dn 13, 1-4]

Legenda o świętej Dorocie. W: Wy d ra, Rze p ka, op. cit., s. 257-260. Przywołując tę i pozostałe legendy o świętych, podawać będę numery wersów. Do królewskiego rodu należy również tytułowa bohaterka staroczeskiego utworu z XVI wieku Legenda o svaté Kateřině (W zb.: Výbor z české literatury od počátků po dobu Husovu. K vydání připravili B. Hav rá n e k, J. H r a bá k a spolupracovníci. Praha 1957, s. 370-382): „O, jaki cud stał się, / Jezu Chryste, z twoją panna, / która była w rozkoszy od młodości / u Kosty, potężnego króla, / jedynaczka w czci i w chwale / u swej matki cnotliwie wychowana, / [...] / [...] jak przystoi jedynej córce / bogatego ojca i matki / tak ona również posiadała / ziemie, zamki, miasta” (w. 282-287, 291-295).

71 Krzywy wysnuł tezę, że wybór Zuzanny na bohaterkę zbliża poemat Kochanowskiego raczej do „poezji romansowej bądź dydaktycznej” niż do epiki „wysokiej” (K 30). Dostrzegając pewne zabiegi, będące intencjonalnym upodobnieniem tekstu do twórczości, w której silnie zaznacza się oralne residuum (np. występowanie postaci kobiecej i dziecięcej, styl utworu nie mający „wiele wspólnego z rejestrem podniosłym” 〈K 30〉), badacz za główne źródła inspiracji nie uznał jednakże wernakularnej hagiografii, lecz właśnie epikę klasyczną.

72 Zob. O 102-103. Kr zy wy określa to jako realizację postulatu mówiącego, by „opisem wyróżniać postaci i miejsca mające znaczenie dla przebiegu fabuły" (K 25). 
- i u Kochanowskiego:

W Assyryjej, na wschód słońca, sławne miasto leży,
Przez które śrzodkiem Eufrates, bystra rzeka, bieży;
Semiramis, mężna pani, ta je zbudowała
Wielkim kosztem, a Babilon imię miejscu dała.
Tam Joachim mieszkał, człowiek dobrego żywota,
Mając wielkie zachowanie i na zamiar złota
Ku dostatku tym go jeszcze fortuna zdobiła,
Że Zuzanna poślubioną jego żoną była:
Białagłowa dziwnie gładka, młoda, urodziwa,
K’temu, co ludzie najdrożej szacuja, cnotliwa.
Iż tedy znaczniejszego wtenczas miasto nie miało,
Na każdy dzień wiele ludzi k’niemu się schadzało.
Przy pałacu był sad piękny, murem otoczony,
Kędy pojźrzał, wszytek na pięć grani usadzony.
A fontana z alabastru prawie pośrzód stała,
Która wodę nieprzebraną ustawicznie lała. [w. 23-38]

Jak widać z porównania, poeta wprowadza takie amplifikacje jak opis miasta, w którym rozgrywają się zdarzenia, oraz deskrypcja ogrodu Joachima - miejsca mającego ważną rolę w fabule utworu - Kochanowski realizuje więc wspomniany już, zabieg dilatatio materiae ${ }^{73}$. Jednocześnie usuwa informacje o sprawiedliwości rodziców Zuzanny (Dn 13, 3). Podobnie postępuje w zakończeniu utworu. Biblijny werset, dotyczący rodziny bohaterki, brzmi:

A Helcjasz i żona jego chwalili Boga za córkę swą Zuzannę z Joakimem mężem jej i ze wszemi powinowatymi, że się nie nalazła w niej rzecz sprosna. [Dn 13, 63]

Kochanowski pomija zarówno ten, jak i ostatni werset, mówiący o dalszych losach Daniela. Joachimowi, mężowi protagonistki oraz jej rodzicom - jako postaciom nie działającym - nie poświęcił poeta odrębnych opisów. Autor eliminuje więc pewne wątki, pozostawiając tylko te, które zamierza prowadzić w swojej wersji historii. Uwage skupia zatem na samej Zuzannie i na wyrokach Bożej sprawiedliwości. Bliscy bohaterki niepotrzebni są w takiej opowieści, dlatego też ich obecność w utworze zminimalizowano. Upraszczając prezentowaną historię, Kochanowski zbliża ją do pieśni wernakularnych, które również były jednowątkowe.

\section{„Gdy ją tedy na śmierć wiedli, dziecię zawołało". Postać dziecka}

W tekście biblijnym pojawia się prorok Daniel (określony słowami „młodzieniec”, „puer iunior"74):

O amplifikacjach w Zuzannie zob. K 23-24.

74 W egzegezie wersetu 13, 45 Pa r ch em (Ksiegga Daniela, s. 720) pisze o określeniach wieku Daniela, występujących w greckich przekładach Biblii: „Podczas gdy w Septuagincie Daniela określa się jedynie jako "neōteros" (młodzieńca, człowieka młodego), w Teodocjonie z emfazą stwierdza się, że był on "paidarion neōteros" (młodym chłopcem). Należy jednak zauważyć, że termin "paidarion", który jest zdrobniałą formą od słowa "pais" (dziecko, młody człowiek), niekoniecznie musi oznaczać, że Daniel był bardzo młody. Termin "paidarion« w ogólnym sensie może oznaczać młodego człowie- 
A Pan wysłuchał jej głosu. Gdy ją prowadzono na stracenie, wzbudził Bóg świętego ducha w młodzieńcu imieniem Daniel. Zawołał on donośnym głosem: „Jestem czysty od jej krwi!” [Dn 13, 44-46] ${ }^{75}$

W wersji zaś Kochanowskiego w tej samej scenie występuje dziecko:

Usłyszał Pan jej rzewny płacz i wnet się zlitował,

Ruszył ducha w Danijelu, aby ją ratował,

Gdy ją tedy na śmierć wiedli, dziecię zawołało:

„Nie chce ja być tej krwie winien!”. Rzekszy to milczało. [w. 167-170]

Dziecko w roli posłańca Bożego pojawiało się w średniowiecznej literaturze hagiograficznej. Przytoczyć można tu fragment Legendy o świętym Aleksym (w. 201-204):

Jedno młode dziecię było,

To jim więc wzjawiło,

A rzekąc: „Aza wy nie wiecie o tym,

Kto to umarł? Jać wam powiem”.

W Legendzie o świętej Dorocie także występuje postać tego typu. Mimo iż stracenie Doroty dokonuje się w lutym (po czesku „únor”), w chwili wykonywania wyroku zjawia się dziecko $z$ koszykiem zawierającym jabłka i róże $z$ Ogrodu rajskiego, co dowodzić ma istnienia Boga i pojmowanych w sposób chrześcijański zaświatów:

Gdyż pod miecz h[a]ławkę nachylała,

Zdarzyć jej $\langle$ się $\rangle \mathrm{w}$ tu chwilu

Dzieciątko wielmi piekne,

Nachym odziane.

$[\ldots \ldots . . .$.

Responsorium

Nosi w koszu owoce:

Trzy jabłka a trzy roże

Unora miesiąca. [w. 104-110]

Przybycie „dzieciątka” wraz z darami staje się przyczyną nawrócenia Teofilusa (w. 115-132).

Kochanowski zastosował zatem, charakterystyczny dla stylu formularnego hagiograficznych pieśni, tradycyjny „temat”76 dziecka, które najczęściej przekazuje reszcie postaci informacje o nie znanej im prawdzie. W Zuzannie ogłasza ono tłumowi najważniejszą wiadomość: o niewinności głównej bohaterki utworu. Od-

ka w wieku pozwalającym na zawarcie małżeństwa [...]. W Rdz 37, 30 słowo "paidarion" jest określeniem Józefa, o którym w 37, 2 mówi się, że miał siedemnaście lat [...]".

W tym przypadku wyjątkowo cytuję przekład współczesny (Pismo Święte Starego i Nowego Testamentu $w$ przekładzie z języków oryginalnych. Oprac. Zespół Biblistów Polskich [...]. Biblia Tysiaclecia. Wyd. 5. Poznań 2013, s. 1222), ponieważ wierniej oddaje się w nim sens określenia „puer iunior", użytego w Wulgacie, i dzięki temu wyraźniej widać modyfikację dokonaną przez Kochanowskiego. W przekładzie W uj k a fragment ten brzmi: „I wysłuchał Pan głosu jej. A gdy ją wiedziono na śmierć, wzbudził Pan ducha świętego pacholęcia młodego, któremu imię Daniel. I zawołał głosem wielkim: Czystym ja jest ode krwie tej".

76 Termin „temat” rozumiem jako: „grupa pojęć używanych regularnie podczas opowiadania historii w stylu formularnym właściwym dla tradycyjnych pieśni” (A. B. Lo r d, Pieśniarz i jego opowieść. Przeł. P. Maje w s ki. Red. nauk. G. G od lew ski. Warszawa 2010, s. 173 〈tam dalsza literatura〉). 
grywa tym samym kluczową rolę w fabule. Podejmując tę konwencję, autor odwołał się do pamięci kulturowej rodzimych odbiorców, znających typową formę żywotów świętych. Dziecko jest w nich „tematem”, wpisanym w oralną tradycję pieśni hagiograficznych, a pojawia się w sytuacjach rozpoznania, śmierci - w momentach granicznych, jak w cytowanych tu przykładach.

Niewyjaśniona wydaje się kwestia tożsamości „dziecięcia” w dziele czarnoleskiego poety. Słownik polszczyzny XVI wieku określa „dziecię” słowami: „nieletni, noworodek, niemowle", i do tego znaczenia zakwalifikowane zostało użycie tego wyrazu w Zuzannie ${ }^{77}$; w Stowniku polszczyzny Jana Kochanowskiego podano zaś definicję: „mały chłopiec lub dziewczynka, niemowlę”78. Nie rozstrzyga to zatem, czy Kochanowski nazwał tak proroka Daniela z racji jego niedorosłości („młodzieniec”, „puer iunior”), czy wprowadził do utworu nowa postać. Jeśli bowiem dziecko jest jednocześnie Danielem, to poeta niekonsekwentnie użył rodzajów gramatycznych: w wersach 169-170 dwukrotnie pojawiają się formy czasownika w rodzaju nijakim: „dziecię zawołało: / "Nie chce ja być tej krwie winien". Rzekszy to milcz ało" (podkreśl. D. V.), co nie koresponduje z dalszą partią tekstu:

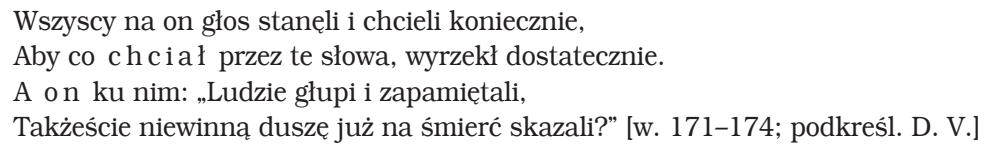

Wygłaszający tę kwestię (bez wątpliwości utożsamić go można z Danielem) określony został jako „on”, a do przedstawienia jego działań używa się rodzaju męskiego. Jeżeli wszakże przyjąc, iż „dziecię" jest dodatkowym bohaterem utworu, znów pojawia się pewna niekoherencja - wypowiada ono mianowicie słowa przypisane w Biblii prorokowi. Tłum zaś pragnie dowiedzieć się prawdy nie od dziecka, lecz od Daniela właśnie. Niespójność konstrukcji tego fragmentu nie dziwi jednak przy założeniu, iż inspiracją Kochanowskiego była rodzima twórczość oralna. Utwory „ustne” bowiem nie rządzą się logiką analityczną, typową dla pisma. Epizody lub elementy wypowiedzi, które do siebie nie pasują, nie są eliminowane, ponieważ owe nieścisłości nie przeszkadzają audytorium nieprzyzwyczajonemu do analizowania treści ${ }^{79}$. Słowo wypowiedziane stanowi „wydarzenie”, a nie „rzecz” - gdy coś raz zostanie wypowiedziane, nie można już przyjrzeć się jego poszczególnym składnikom, jak w przypadku komunikacji pisemnej ${ }^{80}$. Sposób przekazu wpływa więc na model odbierania treści przez słuchacza (bądź czytelnika) ${ }^{81}$.

Zarówno zatem w Zuzannie, jak i w średniowiecznych pieśniach o świętych

S. Beł d ow s ki, Dziecię. Hasło w: Stownik polszczyzny XVI wieku, t. 6 (1972), s. 338.

Dziecię. Hasło w: Stownik polszczyzny Jana Kochanowskiego. T. 1. Red. M. Ku cała. Kraków 1994, s. 458.

Zob. L. Lé vy - Bru h 1, Działania umysłowości prelogicznej. Przeł. B. Szw a r c m a n-Cza rn ot a. W zb.: Świat człowieka - świat kultury. Antologia tekstów klasycznej antropologii. Wybór, red. nauk. E. Nowicka, M. Głowa cka-Grajper. Warszawa 2007, s. 232. Zu m thor (op. cit., s. 327) wyjaśnił to następująco: „W gruncie rzeczy głos łączy, pismo zaś jest jedynie w stanie różnicować pojęcia, które stać się mogą przedmiotem analizy".

Zob. W. J. On g, Pismo a ewolucja świadomości. W: Osoba-świadomość-komunikacja. Antologia. Wybór, wstęp, przekł., oprac. J. J a pola. Warszawa 2009, s. 123-125.

Zob. ibidem. 
dziecko jest tym bohaterem, który z woli Boga obwieszcza dorosłym prawdę ${ }^{82}$. Pojawiając się nagle lub przemawiając niespodziewanie do zbiorowości, staje się „odkrywca cudów"83, łącznikiem między światem codziennym a rzeczywistością metafizyczną.

\section{"Nie był jeden, kto by tej był paniej nie żałował". Inne zabiegi charakterystyczne dla "wtórnej” oralności}

W utworze poety z Czarnolasu zauważyć można także inne środki służące świadomemu zbliżeniu Zuzanny do formy pieśni średniowiecznej, polegające na wprowadzaniu do tekstu tzw. oralności „wtórnej”. Jednym z takich zabiegów jest kreowanie ogólnej perspektywy obserwacji świata ${ }^{84}$. Uwypuklone zostaje zatem zbiorowe przeżywanie emocji, które budzi w społeczeństwie los bohaterki - od sceny pierwszego oskarżenia rzuconego przez starców: „Że się wszyscy słudzy w domu porwali do zbroje” (w. 96), „Z wielkim wstydem wszyscy słudzy tego używali, / Bowiem o niej nic takiego przedtym nie słychali” (w. 99-100), poprzez scenę sądu: „Nie był jeden, kto by tej był paniej nie żałował, / Tak obcy, jako przyjaciel przygody litował" (w. 139-140), aż po ostateczne uniewinnienie protagonistki: „Wszyscy wielkim głosem krzykną i cześć Bogu dali” (w. 207). Porównajmy te cytaty z odpowiednimi fragmentami biblijnymi:

A czeladź domowa usłyszawszy wołanie w sadu werwali się tyłem chcąc widzieć, co by to było. A gdy starcy powiedzieli, zawstydzili się słudzy barzo: bo nigdy nie była mówiona taka mowa o Zuzannie. [Dn 13, 26-27]

A tak płakali przyjaciele jej i wszyscy, którzy ją znali. [Dn 13, 33]

Tedy wszystko zgromadzenie zawołało głosem wielkim i błogosławili Boga, który wybawia pokładających w nim nadzieję. [Dn 13, 60]

Ponadto, tak jak wcześniej wspomniano, autor Zuzanny pominął w zakończeniu poematu watek reakcji rodziny na ocalenie bohaterki (Dn 13, 33):

A Helcjasz i żona jego chwalili Boga za córkę swą Zuzannę z Joakimem mężem jej i ze wszemi powinowatymi, że się nie nalazła w niej rzecz sprosna.

W dziele Kochanowskiego mocnej zaakcentowane zostało zbiorowe przeżywanie losu Zuzanny. W Biblii emocje okazują głównie bliscy bohaterki (domownicy, mąż, rodzice), w wersji czarnoleskiego poety - wszyscy (słowo to wielokrotnie powtarza się w narracji - m.in. w wersach 96, 99, 171, 177, 207). Ową totalizację doświad-

Krzy wy utożsamia dziecko ze starotestamentowym prorokiem: „Daniel jako namiestnik Boga na ziemi, a więc dziecko, które uczestniczy w przebiegu akcji jako bohater istotny, nie należy do postaci typu persona gravis. Są to cechy, którym faktycznie bliżej do religijnej epiki popularnej” (K 30). Badacz zauważa zatem, iż postać dziecka upodabnia utwór do dzieł z zakresu twórczości religijnej, a nie pasuje do jego koncepcji Zuzanny jako „epiki eleganckiej” (K 30); nie zmienia to jednak stanowiska autora.

83 A. Dą brówka, Teatr i sacrum w średniowieczu. Religia-cywilizacja-estetyka. Wyd. 2. Toruń 2013, s. 455. Zob. też N. Te r p stra, Lay Confraternities and Civic Religion in Renaissance Bologna. Cambridge 1995, s. 206.

84 Zob. O 64-65. Badacz ten pisze także o zaangażowaniu emocjonalnym opowiadającego, które ma na celu wciagnięcie audytorium w przedstawiany przez niego świat (O 73). 
czeń bohaterów, jako przejaw oralnego residuum, spotykamy np. w Legendzie o świętym Aleksym, chociażby w scenie poszukiwań zmarłego:

\author{
Samy zwony zwoniły, \\ Wsztki, co w Rzymie były. \\ Więc się po nim pytano, \\ Po wsztkich domiech szukano; [w. 195-198]
}

- oraz w scenie wyjęcia listu z jego rąk (w. 221-226) ${ }^{85}$.

W Zuzannie występuje również wyraźne skontrastowanie postaci, co doskonale pasuje do „silnie spolaryzowanego, agonistycznego, oralnego świata dobra i zła, cnót i wad, łajdaków i bohaterów" (O 72). Widoczne to jest w charakterystykach osób: „A ludzie fałszywi / Na cnotliwą potwarz kładli będąc sami krzywi” (w. 97-98); a szczególnie podkreślone w scenie, w której Zuzanna staje przed swoimi oskarżycielami (w. 130-145): „Nie dali się długo czekać i oni panowie; / U każdego pełno zdrady, pełno fałszu w głowie. / I kazali przed się stanąć Zuzannie cnotliwej” (w. 131-133).

Elementy oralności świadomie wprowadzanej przez Kochanowskiego można dostrzec we fragmencie dotyczacym sądu Daniela nad lubieżnymi starcami (w. 185206). Także tutaj poeta zbliża swój utwór do średniowiecznych pieśni, wykorzystuje bowiem mechanizm homeostazy, tj. przedstawianie życia „w swoistej teraźniejszości” (O 73-74), a „pozbywanie się wspomnień, które przestały mieć znaczenie” (O 74) dla niej ${ }^{86}$. W Biblii, gdy Daniel pyta oskarżycieli, pod jakim drzewem widzieli oni bohaterkę, kolejno padają odpowiedzi: „sub scino” (czyli „pod pistacją) oraz „sub prino” (,pod dębem”) ${ }^{87}$. W Zuzannie gatunki drzew zamienione zostają na jabłoń (w. 193) i orzech (w. 203). Egzotyczną pistację zastąpił zatem Kochanowski rodzimą jabłonia - drzewem, które odbiorcy jego dzieła znają. Autor w ten sposób dostosował tekst biblijny do horyzontu doświadczeń czytelników, w tym adresatki Zuzanny.

Rozmowa proroka ze starcami składa się z dwóch paralelnie skonstruowanych epizodów ${ }^{88}$, ukazujących przesłuchania obu oskarżycieli Zuzanny, zakończone następująco:

85 O mechanizmie totalizacji w Legendzie o świętym Aleksym pisał W oj t o w i c z (Między oralnościa a pismem, s. 199). Egzemplifikacje zbiorowych doświadczeń postaci stanowić mogą również fragmenty staroczeskich utworów, jak choćby cytowanej już Legendy o svaté Kateřině: „I gdy wcześnie wzeszły zorze, / Tak ws zys tki e szaty na siebie założywszy, / panny, swoją służbę wziąwszy, / idzie ku temu pustelnikowi” (w. 11-15; podkreśl. D. V.), czy Legendy o svatém Prokopu z XIV wieku (Výbor z české literatury od počatků po dobu Husovu, s. 359-370 〈cytując utwór, podaję numery wersów w nawiasach )): „Będąc w s zy s c y w tej radzie / w kapitule na Wyszehradzie, / wybrali go na księdza, / na kanonika u świętego Piotra”; „Wówczas ws zy s cy kanonicy, / dziekan, proboszcz i wikariusze / świętego Prokopa wywyższyli, / księdzem go uczynili” (w. 39-42, 53-56; podkreśl. D. V.).

86 Mechanizm ten omawiał Ong (O 73-77). Zob. też Bä u m1, op. cit., s. 249. - Zu m th or, op. cit., s. 328 .

87 Odpowiedzi starców podaję za: Biblia sacra. Iuxta Vulgata versionem (Dn 13, 54; 13, 58). O pojawiających się różnicach w nazwach gatunków drzew pisał W. W a le c ki (Zuzanna. W zb.: Jan Kochanowski. Red. A. G or zkows ki. Kraków 2001, s. 285).

88 Paralelizm epizodów oralnych charakteryzował P. Zu m th or (Właściwości tekstu oralnego. Przeł. M. A b r a m ow i c z. W zb.: Antropologia słowa. Zagadnienia i wybór tekstów. Oprac. G. G o d le wski, A. Mencwel, R. Sulima. Wstęp, red. G. Godlewski. Warszawa 2003, s. 217). 
Powiedział, że pod jabłonią: a na jego mowę

Rzecze Danijel: „Skłamałeś na twą siwą głowę.

Oto Pański anioł stoi, który cię zagładzi.

Z tym precz!" - a drugiego przywieść rozkaże czeladzi. [w. 193-196]

Powiedział, że pod orzechem; a na jego mowę

Rzecze Danijel: „Skłamałeś na twą siwą głowę.

Oto Pański anioł stoi trzymając miecz goły,

A tym z wyroku Pańskiego przetnie cię na poły”. [w. 203-206]

\section{Odpowiednie wersety z Biblii brzmią:}

„Teraz więc, jeśli ją rzeczywiście widziałeś, powiedz, pod jakim drzewem widziałeś ich obcujących ze sobą?” On zaś powiedział: „Pod lentyszkiem”. Daniel odrzekł: „Dobrze! Skłamałeś na swą własną zgubę. Już bowiem anioł Boży otrzymał od Boga wyrok na ciebie, by cię rozedrzeć na dwoje”. [Dn 13, 54-55]

„Powiedz mi więc teraz, pod jakim drzewem spotkałeś ich obcujących ze sobą?” On zaś powiedział: „Pod dębem”. Wtedy Daniel powiedział do niego: „Dobrze! Skłamałeś i ty na swoją własną zgubę. Czeka bowiem anioł Boży z mieczem w ręku, by rozciąć cię na dwoje, by was wytępić”. [Dn 13, 58-59] ${ }^{89}$

Zauważyć więc można - podobnie jak w przypadku zastosowanego mechanizmu totalizacji - iż Kochanowski potęguje pewne cechy tekstu biblijnego, zbliżając go właśnie do wernakularnych utworów przekazywanych ustnie. W Starym Testamencie (szczególnie w wersji $\mathrm{z}$ Wulgaty) oba epizody nie są w tak dużym stopniu paralelne względem siebie, jak te występujące w Zuzannie. Autor przekształcił te sceny $\mathrm{w}$ dwie prawie jednakowe strofy, które kojarzyć się mogą z fragmentami średniowiecznych pieśni, gdzie paralelizmy pełniły np. funkcje mnemotechniczne.

\section{„A tam jawnie Pan swą mocą krwie niewinnej bronił”. Zakończenie utworu}

Tekst czarnoleskiego poety nie zawiera odpowiednika dwóch ostatnich wersetów biblijnej opowieści (Dn 13, 63-64). Mówią one o radości rodziny bohaterki z powodu jej uniewinnienia i o dalszych losach Daniela. Pominięcie tych informacji tłumaczyć zapewne można innym przeznaczeniem utworu. Historia w wersji Pisma Świętego dotyczy przede wszystkim mądrości proroka Daniela w samych początkach jego działalności, tekst Kochanowskiego natomiast - Boskiej sprawiedliwości. Końcowe wersy Zuzanny: „A tam jawnie Pan swą mocą krwie niewinnej bronił, / A jego pomsty straszliwej zły się nie uchronił” (w. 213-214), są zatem podsumowaniem opowieści, jednocześnie zaś powtórzeniem myśli z początku utworu: „Żywie Bóg na niebie, który karze ludzkie złości, / A dobre ma na swej pieczy i każdego broni” (przy czym znów zaobserwować można paralelizm epizodów, charakterystyczny dla oralności).

Cytowany tu współczesny przekład biblijny (Pismo Święte Starego i Nowego Testamentu w przekładzie zjęzyków oryginalnych. Biblia Tysiąclecia, s. 1222) jest wierniejszy Wulgacie, co pozwala łatwiej wyśledzić zmiany (głównie paralelizmy) wprowadzone przez Kochanowskiego. W tłumaczeniu W ujk a fragmenty te brzmia: „Teraz tedy, jeśliś ją widział, powiedz, pod którym drzewem widziałeś je rozmawiające $z$ sobą. Który rzekł: Pod trzmielem. I rzekł Daniel: Prawieś skłamał na głowę twoję, bo oto Anjoł Boży, wziąwszy od niego skazanie, rozetnie cię na poły”; „Teraz tedy powiedz mi, pod którym drzewem pojmałeś je mówiące z sobą? Który rzekł: Pod jodłą. I rzekł mu Daniel: I tyś czyście skłamał na twa głowę, bo czeka Anjoł Pański mający miecz, aby cię rozciął na poły a zabił was”. 


\section{Podsumowanie}

Doświadczenia żony Joachima dowiodły Bożej opieki nad sprawiedliwymi, co zapowiedział Kochanowski w prologu. Zuzanna jest bohaterką statyczną, podobną do postaci świętych $z$ utworów hagiograficznych. Swoim życiem udowodniła przyjęte na początku tekstu założenie, że warto jest być wierna prawdzie i szukać źródła cnoty w wierze w Boga. Protagonistka nie doznaje rozterek moralnych, nie zastanawia się nad tym, co uczynić w chwili niesprawiedliwego oskarżenia - niczym święci ze średniowiecznych żywotów wie, że trzeba zaufać Bogu ${ }^{90}$. W jej rozważaniach nie pojawiają się kwestie „świeckie”91. Należy zatem odrzucić opinię Ziomka, który stwierdził, iż „brak [...] [w Zuzannie] jakiejkolwiek próby chrystianizacji zagadnienia"92. Zuzanna nie jest także - jak chciał Krzywy - przekształceniem narracji biblijnej według wzorców epiki klasycznej, które zbliżałyby polską wersję opowieści do kanonów znajdujących zastosowanie w tworzeniu łacińskich dzieł humanistycznych (zob. K 30). To przeniesienie historii biblijnej na grunt polski wiązało się raczej $\mathrm{z}$ obraniem innej, odpowiedniej ku temu formy. Kochanowski odnalazł ją w zmodyfikowanym wariancie wernakularnej hagiograficznej pieśni. Dzięki owemu zabiegowi zharmonizował biblijną historię $\mathrm{z}$ horyzontem księżnej Radziwiłłowej. Nawiązując do nurtu oralnego i dostosowując się zarazem do świadomości literackiej adresatki, autor wzbogacił swoje dzieło elementami pochodzącymi z innych jeszcze tradycji literackich (antycznej, rodzimej, języka dworskiego). Ukazał tym samym swoją erudycję i umiejętność gry z podjętymi przez siebie konwencjami.

Abstract

DOROTA VINCŮRKOVÁ University of Szczecin

\section{JAN KOCHANOWSKI'S "ZUZANNA" ("SUSANNA") AGAINST THE VERNACULAR CONVENTIONS OF HAGIOGRAPHIC SONGS}

The article takes up Tadeusz Sinko's statement forgotten by scholars that Jan Kochanowski in his poem Zuzanna (Susanna) makes a reference to a convention of medieval vernacular songs about saints. The thesis is proven in the context of the piece's poetics adjustment to cultural experience of its addressee, Elżbieta Radziwiłłowa de domo Szydłowiecka, as well as from the perspective of the women's influence on the development of vernacular literary creativity. The paper also examines the category of virtue contained in the poem and having religious connotations as well as the intentionally introduced by Kochanowski numerous references to oral conventions. Apart from old Polish hagiographic songs, for comparative reasons the article uses examples of old Czech poems. czenie motywu [Zuzanny] [...] w największym nasileniu występuje w utworze Kochanowskiego. Przejawia się ono przede wszystkim w tym, że autor całą historię Zuzanny odnosi głównie do niej jako do kobiety - wzoru cnoty i wierności małżeńskiej, a jednocześnie kobiety bardzo pięknej i wynikających stąd kłopotów osobistych. Gdyby nie zawarte w utworze, nieliczne zreszta, wiadomości o osobach i miejscu akcji, czytelnik nie musiałby wcale wyraźnie kojarzyć tematu wiersza z historią biblijną".

Zob. Mi c hałow s ka, Bohater literacki-pojęcie, s. 102.

Por. uwagi Wa le c ki e go (Motyw Zuzanny i starców w literaturze staropolskiej, s. 45): „ZeświecZi o m e k, O „Zuzannie”, s. 130. Z tezą Ziomka polemizuje także Krzywy (K 29). 